\title{
Provenance of the material on which the name Aloe mendesii Reynolds (Asphodelaceae), a cliff-dwelling species from Angola, is based
}

\author{
Gideon F. Smith ${ }^{1}$ and Estrela Figueiredo 2 \\ ${ }^{1}$ Office of the Chief Director: Biosystematics Research \& Biodiversity Collections, South African National \\ Biodiversity Institute, Private Bag X101, Pretoria, 0001 South Africa / H.G.W.J. Schweickerdt Herbarium, \\ Department of Plant Science, University of Pretoria, Pretoria, 0002 South Africa and Centre for Functional \\ Ecology, Departamento de Ciências da Vida, Universidade de Coimbra, 3001-455 Coimbra, Portugal \\ (email: g.smith@sanbi.org.za). \\ 2 Department of Botany, P.O.Box 77000, Nelson Mandela Metropolitan University, Port Elizabeth, 6031 \\ South Africa / Centre for Functional Ecology, Departamento de Ciências da Vida, Universidade de Coimbra, \\ 3001-455 Coimbra, Portugal (email: estrelafigueiredo@ hotmail.com).
}

Summary: Aloe mendesii Reynolds (Asphodelaceae) is a distinctive cliff-dwelling species from southern Angola. It is one of the few species of Aloe L. that Dr G.W. Reynolds described using immature flowering material. Although the name has an unambiguously designated holotype, up to now uncertainty existed as to the origin of the material on which it was based. It is shown conclusively that Dr Eduardo Mendes sent material that he obtained from Mr J. Brito Teixeira to Reynolds in Swaziland. Reynolds described the new species in 1964 from this material, naming it for Mendes. However, the type was collected by Sr R. [Romeu Mendes dos] Santos and Sr C. [Carlos Alves] Henriques, under the number Santos \& Henriques 1131, at Tundavala on 4 July 1963, a year before Reynolds published this new name.

Zusammenfassung: Aloe mendesii Reynolds (Asphodelaceae) ist eine gut charakterisierte, Felsen bewohnende Art aus dem südlichen Angola. Es ist eine der wenigen Arten von Aloe L. die Dr. G. W. Reynolds auf der Basis von unreifem blühendem Material beschrieben hat. Obwohl der Name einen eindeutig bezeichneten Holotyp hat, existieren bis heute Unsicherheiten bezüglich der Herkunft des Materials, auf dem er basiert. Hier wird überzeugend dargelegt, dass Dr. Eduardo Mendes das Material von Herrn J. Brito Teixeira erhalten und an Reynolds in Swaziland geschickt hatte. Reynolds beschrieb die neue Art 1964 auf der Basis dieses Beleges und benannte es nach Mendes. Der Typ wurde jedoch von Sr. R. [Romeu Mendes dos] Santos und Sr C. [Carlos Alves]
Henriques am 4. Juli 1963 bei Tundavala unter der Nummer Santos \& Henriques 1131 gesammelt, d.h. ein Jahr bevor Reynolds den neuen Namen publizierte.

\section{Introduction}

A total of 28 species of Aloe L. are known from Angola (Figueiredo \& Smith, 2008, 2009; Klopper et al., 2009, 2010). At least three of these, A. palmiformis Baker, A. littoralis Baker and A. mendesii Reynolds (Verdoorn, 1978), are found at Tundavala near Lubango (formerly known as Sá da Bandeira) in southern Angola, two of them (A. palmiformis and A. mendesii) being endemic to the country. A. mendesii (Figure 1) is an obligate cliff-dweller (cremnophyte), growing in almost entirely inaccessible positions on near-vertical cliff faces (Figure 2) in Huíla Province in southern Angola (Figure 3). The species was described in 1964 by the late Dr Gilbert Westacott Reynolds, well-known aloe expert (Walker, 2010), eight years after Dr Eduardo José Santos Moreira Mendes originally found and photographed it in January 1956 (Reynolds, 1966: Figure 173). There is no indication in Mendes's field notebook from 1956 suggesting that he collected the species in that year and no herbarium specimens of this species dating from that time are known. Mendes did, however, collect other specimens at that locality (Bimbe, which is $25 \mathrm{~km}$ west of Sá da Bandeira) and at that time. He simply could not reach a specimen to collect as the apparently soilless cracks and depressions in the cliffs where this species grows are indeed very 


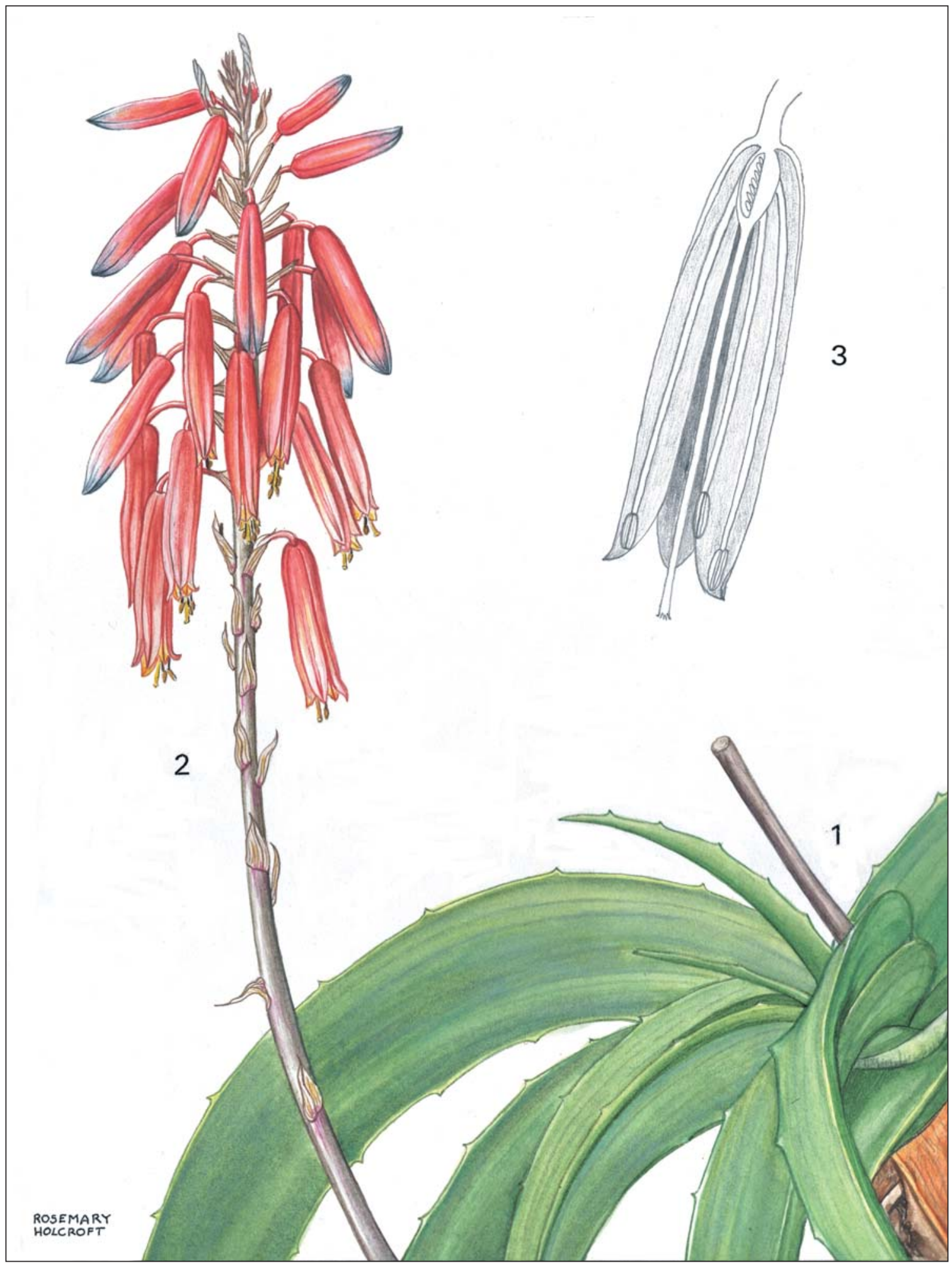

Figure 1. Plate of Aloe mendesii from Verdoorn (1978). Reproduced with permission of the South African National Biodiversity Institute (SANBI). 
difficult to reach (Dr Eduardo Mendes, personal communication). He originally observed plants on cliffs of the Serra da Chela, on the western escarpment of the Humpata plateau at Bimbe (Reynolds, 1964).

Reynolds did not encounter the species in the wild when he undertook a collecting trip to Angola in 1959 (Reynolds, 1960), even though he visited Lubango (Sá da Bandeira), which is a known locality of $A$. mendesii (see Reynolds, 1960: 15 for a map of the route he travelled during his visit to Angola). It is therefore unlikely that Mendes mentioned its occurrence at and near those localities to him, because Reynolds surely would have searched for, or at least mentioned, this interesting species in his travelogue. Reynolds's one and only trip to Angola (1959) preceded that of Mendes's second expedition which took place in late-1959 and early-1960. During that trip, on $22^{\text {nd }}$ April 1960, Mendes certainly collected the species at Buraco do Bimbe, near Humpata, at an altitude of 2,220 m (Mendes 3815, LISC).

\section{Material on which the name Aloe mendesii is based}

Reynolds eventually received the living material which he cultivated at Mbabane, Swaziland, and on which he based the first description of the species, from Dr Mendes (see the 'Acknowledgements' in Reynolds, 1964: 32). He states (Reynolds, 1964: 31), however, that Sr R. [Romeu Mendes dos] Santos and Sr C. [Carlos Alves] Henriques, both of the Instituto de Investigação Científica de Angola, Luanda, collected plants of A. mendesii on the Bimbe, and rediscovered and collected material of it on the Tundavala escarpment (where Figure 2 was taken) which is about $18 \mathrm{~km}$ (11 miles) northeast of Bimbe and $16 \mathrm{~km}$ (10 miles) northwest of Lubango (Sá da Bandeira). A specimen, Santos \& Henriques 1131 (kept in LISC), that these two gentlemen collected at Tundavala on $4^{\text {th }}$ July 1963, a year before Reynolds published this new name, served as the holotype of the name A. mendesii. The specimen Santos 1109 (kept in LISC) of $A$. mendesii, which was collected on $3^{\text {rd }}$ May 1963, consisted of a leaf and a portion of an undeveloped raceme only (Reynolds, 1964), and was collected by Santos at the request of Mendes. The earlier Mendes specimen of this species, Mendes 3815, therefore did not serve as the type, because the inflorescence was very young and the flowers were still immature when it was pressed in April 1960 (Reynolds, 1966: 171), the same being applicable to the specimen Santos 1109.

In correspondence from Reynolds to Mendes, dated $17^{\text {th }}$ April 1963, Reynolds states that he was “...delighted to hear that Prof. Resende collected [possibly meaning 'obtained'] 2 plants of your Bimbe aloe - EJM 3815 \& that they are growing in the Bot. Garden at Lisbon University. I do hope that it will be possible one day for me to obtain a plant of this new sp to grow here. I would love to name this new species after you - if I could!" Whether Reynolds ever received the Resende material is not known, as he designated the Santos and Henriques collection as the type of the name. Furthermore, Mendes confirmed (personal communication on $23^{\text {rd }}$ September, 2010) that he sent living material of $A$. mendesii to Reynolds to grow in Mbabane. This material was collected by Mr J. Brito Teixeira who took the material to Lisbon from Angola when he went there on leave. A specimen from this material was grown by Mendes in Sintra, near Lisbon, but it did not survive long in the Mediterranean climate prevalent there. In this instance it would therefore appear that Reynolds used Teixeira material, of which a herbarium specimen was not prepared, to compile the description, but designated Santos \& Henriques material as the type. The fate of material obtained by Resende remains unknown. Works of Prof. Flávio P. de Resende (1907-1967) are wellknown to students of aloes and their kin as much of his pioneering cytological research was conducted on these plants and their relatives, especially haworthias (see for example Resende, 1943, and Riley \& Majumdar, 1979, for references). He was a Professor of botany at the University of Lisbon from 1943 to 1967 and Director of this University's Botanical Garden.

The 86-year old Dr Mendes $\left(26^{\text {th }}\right.$ November 1924-) still resides in Lisbon, Portugal (Figure 4). Even though he only participated in two botanical expeditions to Angola, several thousand of the herbarium collections he amassed during his career originate from this former Portuguese colony. The first expedition took place in September 1955 to March 1956 and focused mostly on the southwestern parts of the country, where Mendes collected 1,750 numbers. The second expedition took place between December 1959 and May 1960, mostly in the southeastern region, between $\mathrm{Cu}$ vango and Cuito-Cuanavale, and resulted in the numbers 1,800 to 4,064 in Mendes's collection (Mendes, 1980). Some of these specimens collected decades ago are still being used as the types of new plant names, including some succulents. Filipe de Sousa, currently of the University of Gothenburg, in Sweden, and the two authors of this note, recently described the succulentstemmed Cyphostemma mendesii based on some of Mendes's material (Sousa et al., 2010). To this can be added about 13 further taxa described 


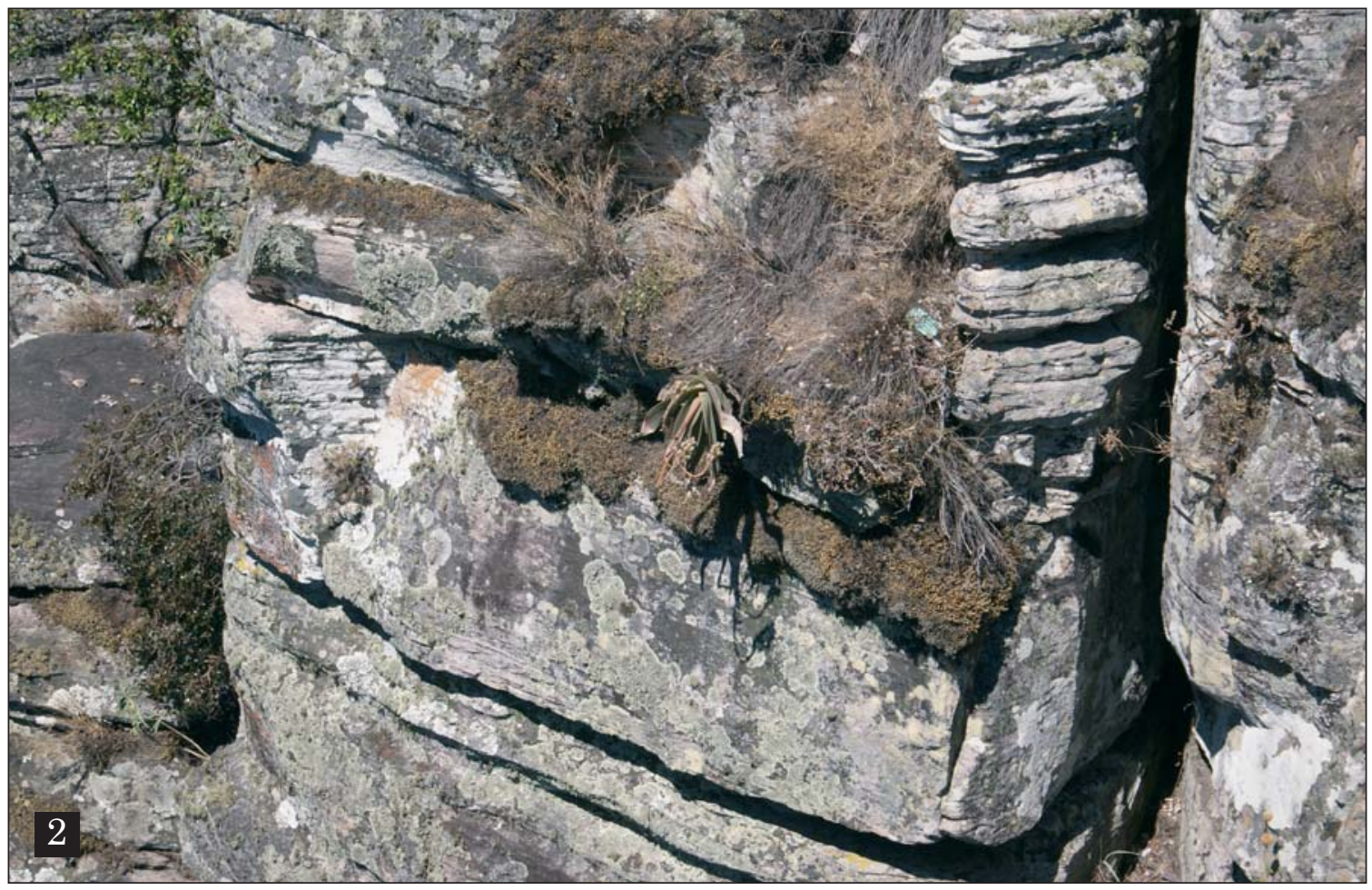

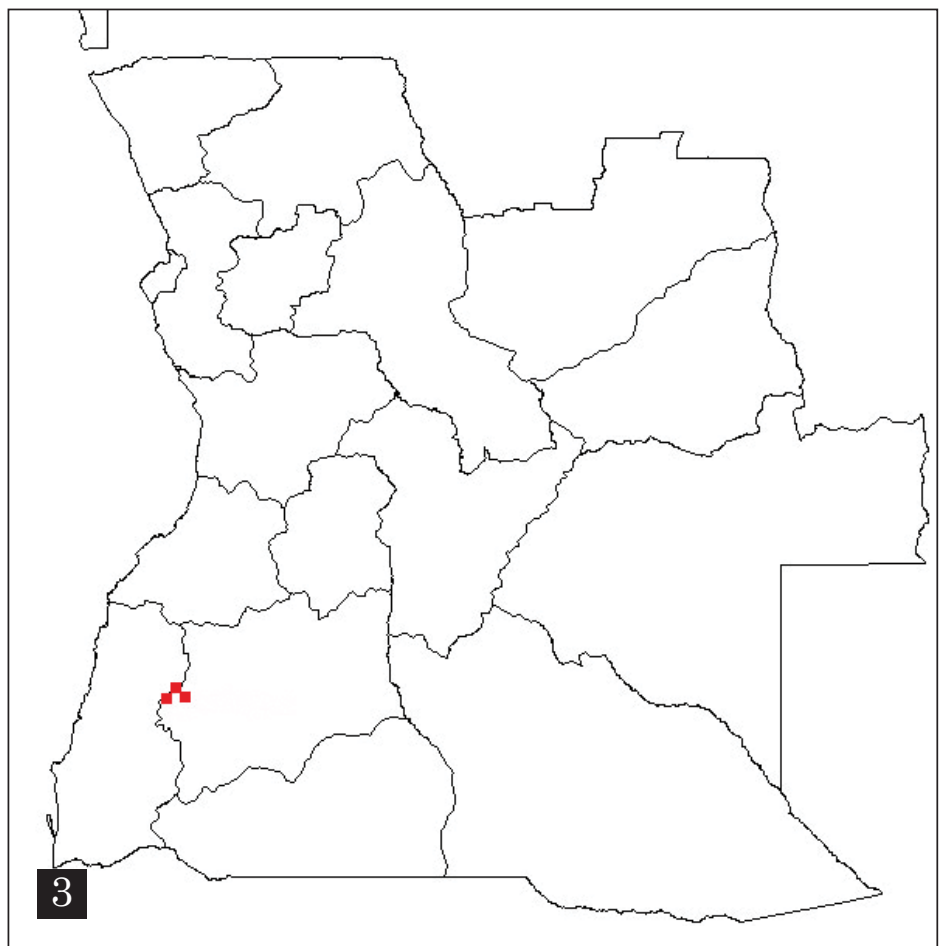

Figure 2. The near-vertical cliffs along the Tundavala plateau, southern Angola, harbour Aloe mendesii. Photo: Gideon F. Smith, $7^{\text {th }}$ August, 2010. Figure 3. Geographical distribution range of A. mendesii in southern Angola. from, and named for, Eduardo Mendes from collections he made in Angola. Eleven are currently accepted, including the distinctive succulent tree Euphorbia eduardoi L.C. Leach (Figure 5). His first name was used in this commemoration because Euphorbia mendezii Boiss., a Mexican species, was earlier described and named for a collector named Mendez. In 1974, Mendes became Director of the Centro de Botânica, in Lisbon, Portugal. Throughout his career he maintained an interest in the floras of Angola and Mozambique, and did considerable work on these.

\section{Nomenclature of Aloe mendesii} Aloe mendesii Reynolds in J. S. Afr. Bot. 30: 31-32, pls. X-XI (1964). Reynolds in Aloes of tropical Africa and Madagascar: 170-171 (1966); Verdoorn in Flow. Pl. Afr. 45: t.1764 (1978); Court in Succulent flora of Southern Africa: 139 (icones), 155 (1981); Court in Succulent flora of Southern Africa, revised edition: 243 (icones), 255 (2000); Newton in Illustrated handbook of succulent plants. 

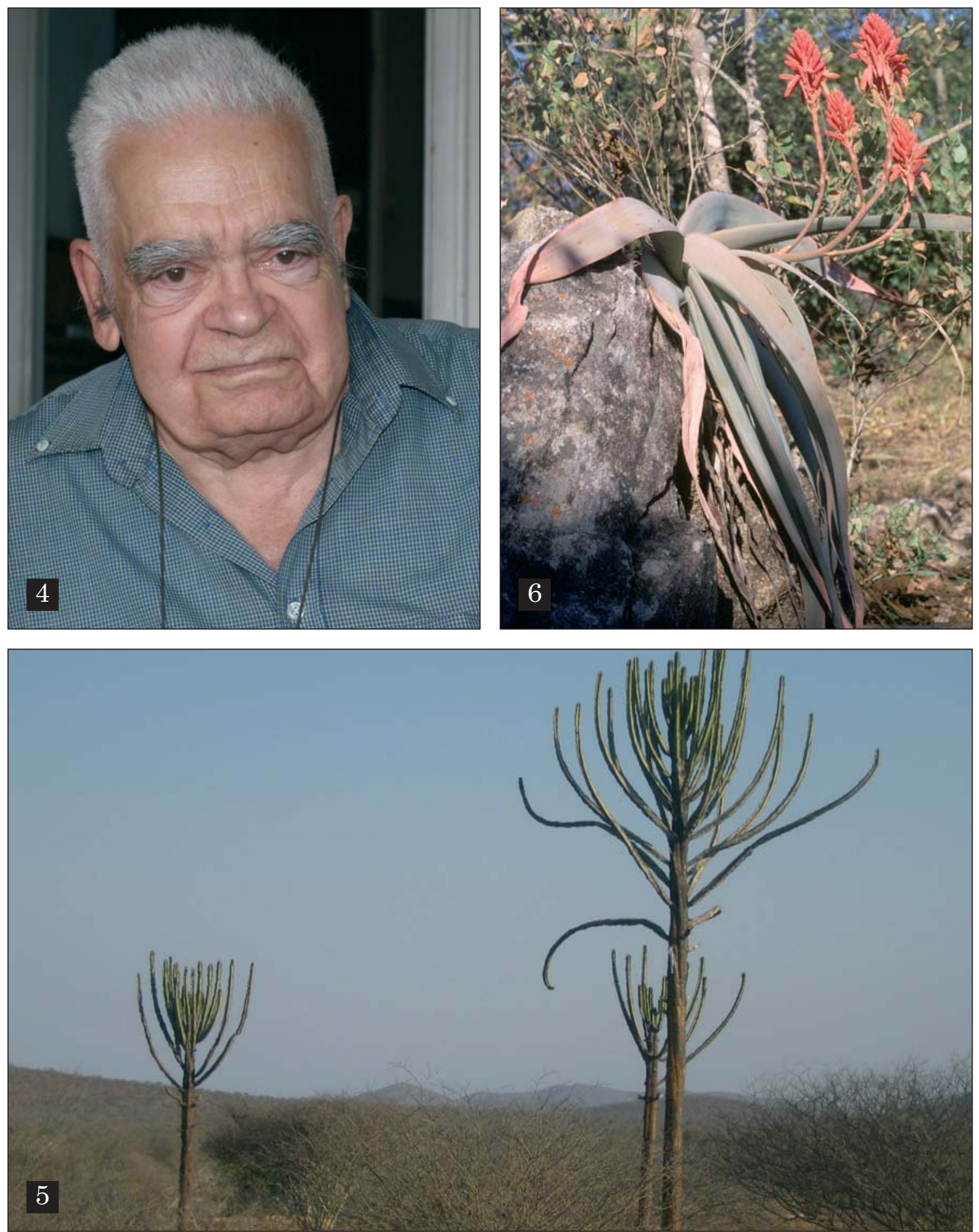

Figure 4. Eduardo Mendes (26 $6^{\text {th }}$ November 1924-) for whom Aloe mendesii was named. Photo: Gideon F. Smith, $23^{\text {rd }}$ September, 2010. Figure 5. Euphorbia eduardoi L.C.Leach growing along the road leading from Lubango to Namibe, Angola, commemorates Eduardo Mendes. Photo: Estrela Figueiredo, $6^{\text {th }}$ August, 2010. Figure 6. Image of $A$. mendesii taken by the late Mr L.C. (Larry) Leach. SANBI slide collection. Reproduced with permission. 
Monocotyledons: 154 (2001); Klopper et al. in Bothalia 39: 29 (2009); Klopper et al., 2010: 39; Court in Succulent flora of Southern Africa, revised edition: 279 (icones), 286 (2010).

Holotype: Santos \& Henriques 1131 (LISC). Paratype: Mendes 3815 (LISC). Additional material examined: Leach 14015 (PRE); Menezes 1133 (PRE); Santos 1109 (LISC).

\section{Aloe mendesii in ex situ cultivation}

As far as we could ascertain $A$. mendesii remains uncommon, if not entirely unknown, in ex situ cultivation. Specimens cultivated in Lisbon in the 1960s did not survive, and we could find no indication that material from Reynolds's collection in Swaziland or at the Pretoria National Botanical Garden is still in cultivation. However, the images of this species included in Court (1981, 2000, 2010) are of material grown in a container. The historical image of a plant of $A$. mendesii, taken by the late Mr L.C. Leach (Figure 6), appears to be of material found in its natural habitat, but the setting also bears a close resemblance to a plant growing in the Botanical Garden in Chianga, Angola, in 1971 (black \& white photograph examined in the LISC Herbarium by the authors). Although the species has a fairly small world population, at least in terms of the general size of most Aloe populations, the species grows in such inaccessible places in southern Angola that only a major natural catastrophe would impact negatively on its in situ survival.

\section{Acknowledgements}

Dr Eduardo Mendes, formerly Director of the Centro de Botânica, in Lisbon, Portugal, is thanked for providing additional information about the collections on which G.W. Reynolds based the name A. mendesii. Ms Joana Abreu is thanked for providing information from the library of Centro de Botânica and Herbarium LISC in Lisbon. Permission granted by the South African National Biodiversity Institute to reproduce the plate (Figure 1) and image (Figure 6) of A. mendesii is gratefully acknowledged.

\section{References}

CourT, D. (1981). Succulent flora of Southern Africa. A.A.Balkema, Cape Town.

CourT, D. (2000). Succulent flora of Southern Africa, revised edition. A.A.Balkema, Rotterdam.
CourT, D. (2010). Succulent flora of Southern Africa, revised edition, Struik Nature, Cape Town.

Figueiredo, E. \& Smith, G.F. (2008). Plants of Angola / Plantas de Angola. Strelitzia 22. South African National Biodiversity Institute, Pretoria.

Figueiredo, E. \& Smith, G.F. (2009). The succulent flora of Angola. Haseltonia 15: 69-78.

Klopper, R.R., Matos, S., Figueiredo, E. \& SMith, G.F. (2009). Aloe in Angola (Asphodelaceae: Alooideae). Bothalia 39: 19-35.

Klopper, R.R., Matos, S., Figueiredo, E. \& SMith, G.F. (2010). A preliminary checklist for the aloes of Angola. In VAN DER BURGT, X., VAN DER Maesen, J., OnAnA, J. \& J.-M. (eds.) Systematics and conservation of African plants. Proceedings of the XVIIIth triannual Congress of the AETFAT, Yaoundé, Cameroon. Kew Publishing, Royal Botanic Gardens, Kew, pp. 3741.

Mendes, E.J. (1980). A Junta de Investigações Científicas do Ultramar e a flora de África: Missões e Centro de Botânica. Bol. Soc. Brot. Sér.2, 54: 201-215.

Newton, L.E. (2001). Aloe. In EGGLI, U. (ed.) Illustrated handbook of succulent plants: Monocotyledons. Springer, Berlin, pp. 103186.

Resende, F. (1943). Suculentas africanas III. Contribuição para o estudo da morfologia, da fisiologia da floração e da geno-sistemática das Aloineae. Mem. Soc. Brot. II: 5-119.

REYNOLDS, G.W. (1960). Hunting aloes in Angola. Afr. Wild Life 14: 13-25.

Reynolds, G.W. (1964). A new Aloe from Angola [Aloe mendesii]. J. S. Afr. Bot. 30: 31-32, pls. $\mathrm{X}-\mathrm{XI}$.

Reynolds, G.W. (1966). Aloes of tropical Africa and Madagascar. The Aloes Book Fund, Mbabane, Swaziland.

RILEY, H.P. \& MAJUMdAR, S.K. (1979). The Aloineae. A biosystematic survey. The University Press of Kentucky, Lexington.

Sousa, F., Figueiredo, E. \& Smith, G.F. (2010). Cyphostemma mendesii (Vitaceae), a new species from Angola. Phytotaxa 7: 35-39.

Verdoorn, I.C. (1978). Aloe mendesii. Angola. Liliaceae. Flow. Pl. Afr. 45: t.1764.

WALKER, C.C. (2010). Gilbert Westacott Reynolds: his study of Aloe and a bibliography of his work. Bradleya 28: 111-124. 